\title{
Kronik böbrek yetmezlikli hastalarda erektil disfonksiyon ve hiperhomosisteinemi ilișkisi
}

\author{
Correlation between erectile dysfunction and hyperhomocysteinemia \\ among men with chronic renal failure
}

Emrah Sarı ${ }^{1}$, Mustafa Faruk Usta²

öz

GíRiș ve AMAC: Erektil disfonksiyon (ED), tatmin edici bir cinsel aktivite için gerekli olan ereksiyonun sağlanamaması ya da sağlansa bile devam ettirilememesidir. Ereksiyon fizyolojisinde nitrik oksit (NO) aracılı kavernöz düz kas gevşemesi primer rol oynamaktadır. Homosistein (Hcy), esansiyel bir aminoasit olan metiyoninden sentezlenen sülfür içeren bir aminoasittir. Deneysel modellerde, ateroskleroz ve bozulmuş kavernozal kan akımına neden olan hiperhomosisteineminin (HHcy) ED gelişiminde bağımsız bir faktör olabileceği açıklanmıştır. Öte yandan, ED kronik böbrek yetmezlikli (KBY) hastalar arasında sık karșılașılan bir patolojidir. Hemodiyalize giren hastalarda HHcy prevalansı \%90 oranında görülür.

YÖNTEM ve GERECLER: Bu çalıșmanın amacı: KBY olan hastalarda ED ve serum HHcy düzeyleri arasındaki olası ilișkinin araștırılmasıdır. Çalışmaya 25-65 yaş arası 34 tanesi KBY nedenli hemodiyaliz (HD) hastası olan 92 erkek katıldı. Hastalar prospektif olarak; HD'e giren ED'si olan (Grup-1), HD'e giren ED'si olmayan (Grup-2), KBY'si olmayan ED'si olan (Grup-3), ve KBY'si olmayan ED'si olmayan (Grup4) olmak üzere dört gruba ayrıldı. Grupların ED sınıflaması IIEF sorgulama formu ile yapıldı. ED ile ilgili ko-morbiditesi olan ya da ED nedeni olabilecek cerrahi girişim öyküsü bulunan hastalar çalışma dışı bırakıldı. Tüm hastalarda serum glukoz, total testosteron ve homosistein ile ED ile ilişkili olabilecek diğer parametrelerin ölçümü yapıldı. ED ile ilişkili ko-morbid hastalığı olan ya da cerrahi girişim geçiren hastalar çalışmaya alınmadı.

BULGULAR: Sonuçlar karşılaştırıldığında bu dört grup arasında Hcy düzeyleri arasında istatistiksel açıdan anlamlı fark bulunmadı. Buna karșılık ED grupları hafif-orta ve ileri olarak sınıflandırıldığı takdirde; HD’ye giren şiddetli+orta ED'si olan grup ile, HD'ye girmeyen şiddetli+orta ED'si olan grup arasında Hcy seviyeleri arasında istatistiksel açısından anlamlı fark olduğu saptandı $(\mathrm{p}=0,003)$.

TARTIȘMA ve SONUC̦: Çoklu lojistik regresyon analizi yapıldığında artmış Hcy seviyelerinin ED gelişimde yaştan bağımsız risk faktörü olduğu saptand.

Anahtar Kelimeler: Homosistein, erektil disfonksiyon, kronik böbrek yetmezliği

\section{ABSTRACT}

INTRODUCTION: Erectile dysfunction (ED) is the inability to achieve and maintain an erection sufficient for satisfactory sexual intercourse. Relaxation of cavernous smooth muscle mediated by nitric oxide (NO) plays a primary role in the physiology of penile erection. Homocysteine (Hcys) is an essential amino acid containing sulfur and is synthesized from methionine. Experimental models have elucidated the role of hyperhomocysteinemia (HHcy) as a strong and independent predictor for atherosclerosis progression and impaired cavernosal perfusion, which leads to ED. On the other hand, ED is a common condition among men with chronic renal failure (CRF). The prevalence of hyperhomocysteinemia is more than $90 \%$ in men who undergo hemodialysis (HD).

METHODS: The aim of this study is to determine if there is a correlation between ED and HHcy among men with CRF. A total of 92 men between 25-65 years of age participated in the study, from which 34 of them were HD patients caused by CRF. Four groups of patients were utilized including: CRF-HD patients with ED (Group-1), CRFHD patients without ED (Group-2), patients with ED (Group-3) and patients without ED (Group-4). ED has been evaluated by using the Turkish version of International Index of Erectile Function questionnaire (IIEF). Patients with any co-morbidity related to ED or patients who underwent surgical intervention related to postoperative ED development were excluded from the study. Serum glucose, total testosterone and homocystein and other parameters which suppose to cause ED were measured in all patient groups.

RESULTS: The results of the present study showed that there was no statistically significant difference for serum homocystein levels between the study groups. On the other hand, when ED groups are categorized as severe+moderate and mild, a significant difference concerning Hcy levels has been found between the groups with advanced ED either having CRF-HD and patients without CRF-HD ( $\mathrm{p}=0.003)$.

DISCUSSION AND CONCLUSION: Additionally, by using ordinal logistic regression analysis it has been found that increased Hcy levels is an independent risk factors for erectile dysfunction.

Keywords: Homocysteine, erectile dysfunction, chronic renal failure
${ }^{1,2}$ Akdeniz Üniversitesi Tıp Fakültesi Üroloji Anabilim Dalı, Antalya, Türkiye

Yazıșma Adresi/ Correspondence:

Prof. Dr. Mustafa Faruk Usta

Akdeniz Üniversitesi Tıp Fakültesi Üroloji Anabilim Dalı, Antalya, Türkiye

Tel. $\quad$ +902164413900/1809

E-mail: mususta53@hotmail.com

Gelis/Received: $\quad 06.06 .2017$

Kabul/Accepted: $\quad 07.06 .2017$

\section{GíRiș ve AMAÇ}

Kronik böbrek yetmezliği (KBY) hastalarında erektil disfonksiyon (ED) sık görülen bir yakınmadır. KBY ile ile ilişkili ED patofizyolojisinde hormonal faktörler, psikojenik faktörler, endotelial disfonksiyon, otonom nöropati ve eritropoetin eksikliğinin rol oynadığı rapor edilmiştir. ${ }^{[1-3]}$ 
Navaneethan ve ark. ${ }^{[4]}$ kendi meta-analiz çalışmalarında KBY'li hastalarda ED'nin prevalansını ortalama \%70 olarak bulmuşlardır. Ek olarak Mesquita ve ark. ${ }^{\left[{ }^{[5}\right.} \mathrm{KBY}$ evre 3, 4 ve 5 olan bireylerdeki ED prevalansını sırasıla; \%72,3, $\% 81,5$ ve \%85,7 olarak raporlamışlardır. Nassir, diyaliz programına alınan bireylerdeki ED prevalansını \%82,7 olarak bildirmiştir. ${ }^{[6]}$ Tüm bu sonuçlar, ED'un $\mathrm{KBH}$ olan hastalarda sıklıkla ortaya çıktığını göstermektedir. Tüm bunların dışında, KBY hastalarında serum homosistein düzeylerinde yükselme olduğu birçok çalışmada gösterilmiştir. Bu çalışmaların sonuçları hastaların \%85-100'ünde hiperhomosisteineminin mevcut olduğu ve serum homosistein düzeyinin 2-3 kat arttığını ortaya koymuştur. ${ }^{[7,8]}$

Homosistein; kardiyovasküler, serebrovasküler ve periferik vasküler hastalıklarda bağımsız bir risk faktörü olarak kabul edilmektedir. Hiperhomosisteinemi (HHcy) vasküler dokuda bozulmuş Nitrik Oksit (NO) aracilı relaksasyon ile ilişkilidir. Penil ereksiyon fizyolojisinde endotelden sal1nan NO aracılı kavernozal düz kas relaksasyonu primer rol oynamaktadır. Bu nedenle HHcy'nin vaskülojenik ED için bir risk faktörü olabileceği düşünülebilir. ${ }^{[8-10]}$

HHcy ile ED arasındaki ilişkiyi gösteren in vivo ve in vitro çalışmalar bulunmakla birlikte, literatürde KBY'li hastalarda erektil disfonksiyon ve hiperhomosisteinemi arasındaki ilişkiyi gösteren bir çalışma bulunmamaktadır.

Çalışmamızda koroner arter hastalığında bağımsız risk faktörü olan HHcy'nin; ED'li KBY hastalarında da bağımsız bir risk faktörü olabileceği düşünülerek, aradaki olası ilişkinin varlığg araştırılmıştır.

Bu ilişkiyi ortaya koyabilmek adına ED'si olan ve olmayan hemodiyaliz (HD) programındaki non-diyabetik KBY hastaları ile non-diyabetik, KBY'si olmayan ancak ED'si olan ve normal sağlıklı kişilerden oluşan kontrol gruplarının erektil fonksiyonları ile serum homosistein düzeylerini objektif veriler ışığında incelemeyi hedefledik.

\section{GEREÇ Ve YÖNTEM}

Çalışmamızda, 25-65 yaşları arasında (ortalama $48,47 \pm 11,25)$ toplam 92 erkeğin, IIEF anketleri ile erektil fonksiyonları sorgulanmıştır. Katılımcılardan 34 tanesi süre olarak en az üç ay olmak şartı ile düzenli hemodiyaliz programındaydı. Diğer 58 hastayı üroloji polikliniğine erektil disfonksiyon (ED) şikayetiyle başvuran erkekler oluşturdu. Katılımcılara verilen sorgulama formları ile hemodiyalize giren KBY'li hastalar ve böbrek fonksiyonları normal sınırlar arasında olan katılımcılar iki ana gruba, bu gruplar da ED olup olmamasına göre yine kendi arasında ikişer gruba ayrıldı.
Alt gruplardan birincisi KBY ve ED olan hastalardan, ikincisi KBY'li olan ve ED bulunmayan hastalardan oluşturuldu. KBY'si olmayan kişilerde aynı şekilde ED olan ve olmayan şeklinde iki gruba ayrıldı.

Gruplar oluşturulurken, IIEF anket skoru 22 ve üstü olan kişilerde ereksiyon fonksiyonu normal değerlendirilip, kontrol grubu olarak isimlendirildi. IIEF skoru 22'nin altı olan kişiler ise ED olan grubu oluşturuldu. Bu grup IIEF skoru 12'nin altı ve 12-22 arası olarak iki alt gruba ayrıldı. On iki ve altı olan grup şiddetli+orta derecede ED, 12-22 arası skoru sahip hastalar ise hafif derecede ED'a sahip hastalar olarak değerlendirildi.

Çalışmaya dahil edilen kişilerin özellikle diabetes mellitus, koroner arter hastalığı, hipertansiyon, hiperlipidemi, tiroid hastalıkları gibi ED etyolojisinde rol oynadığı bilinen kronik hastalıklara sahip olmamasına dikkat edildi. Ayrıca hastaları daha öncesinde geçirilmiş ürolojik veya pelvik cerrahi öyküleri sorgulandı. Geçirilmiş cerrahi öyküsü olanlar çalışma dışında bırakıldı.

Çalışma gruplarından alınan açlık venöz kan örneklerinden; açlık kan şekeri, LDL, HDL, trigliserit, total kolestrol, testosteron düzeyleri ölçüldü. Değerleri normal sınırlar d1şında olanlar çalışma dışı bırakıldı. HD programında olan hastalardan alınan kan numuneleri diyaliz öncesi alındı. Hastaların boy, kilo ve tansiyonları ölçülerek kaydedildi.

Homosistein düzeyini ölçmek amacıyla alınan kan örnekleri standart EDTA'lı tüplere 5 cc olarak alınmıştır. Örnekler buz aküleri ile muhafaza edilerek ölçüm amaciyla laboratuvara teslim edilmiştir. 2500 RPM'de 10 dakika santrifüj edilen numunelerin plazma bölümü ayrılarak; $-20^{\circ} \mathrm{C}$ de analiz edilene kadar saklanmıştır.

İstatistiksel olarak karşılaştırılan verilerin normallik varsayımı sağlanamadığı için, gruplar arası farkın önem kontrolünde Mann-Whitney U ve Kruskal Wallis testleri kullanılmıştır. ED düzeylerini etkileyen faktörleri bulmak için sıralı lojistik regresyon analizi SPSS 18 istatistik paket programı kullanılarak yapılmıştır.

\section{BULGULAR}

Çalışmaya alınan 92 katılımcının ortalama yaşı $48,47 \pm 11,25$ idi. Katılımcılar demografik ve laboratuvar sonuçları Tablo 1'de verilmiştir.

Katılımcılar; Hemodiyalize giren ED'si olan, Hemodiyalize giren ED'si olmayan, hemodiyalize girmeyen ED'si olan, hemodiyalize girmeyen ED'si olmayan olmak üzere dört gruba ayrıldı. Gruplardan elde edilen sonuçlar değerlendirildiğinde; ED bulunan gruplarda ortalama Hcy değerinin, 
Tablo 1. Katılımcıların demografik özellikleri ve laboratuvar analiz sonuçları

\begin{tabular}{ll} 
Kişi sayısı & 92 \\
Yaş & $48,47 \pm 11,25$ \\
Hcy & $9,98 \pm 5,33$ \\
Total testosteron & $3,26 \pm 1,42$ \\
LDL & $99 \pm 2,7$ \\
Total kolestrol & $164 \pm 35,7$ \\
Glukoz & $90,3 \pm 12,77$ \\
VKi & $25,89 \pm 3,44$ \\
HDL & $39,7 \pm 8,98$ \\
Trigliserit & $144,1 \pm 61,5$ \\
HD'ye giren sayı & 33 \\
& Hipertansiyon (11 kişi) \\
KBY etyoloji & Polikistik böbrek hast. (3 kişi) \\
& Glomerülonefrit (3 kişi) \\
Sigara içen & 45 kişi \\
\hline
\end{tabular}

erektil disfonksiyonu olmayan gruplara göre yüksek olduğu gözlendi. Buna karşılık Kruskal Wallis testi ile yapılan değerlendirme sonucu; gruplar arasında saptanan Hcy değerleri arsındaki farklılığın istatistiksel açıdan anlamlı olmadığı tespit edildi. Buna karşılık gruplar arasında yaş, total testosteron ve VKİ değerleri arasında anlamı bir farklılığın olduğu saptandı (Tablo 2).
Ek olarak gruplardan elde edilen değerler Mann Whitney-U testi kullanılarak istatistiksel anlamlılık açısından değerlendirildi. Buna karşılık gruplar arasında ortalama Hcy değerleri açısından anlamlı fark bulunamadı. Buna karşılık Grup 1 ve Grup 3 arasında serum testosteron düzeyleri açısından anlamlı bir farklılığın olduğu tespit edildi (Tablo 3). Diğer grupların ikili karşılaştırması sonrası serum testosteron düzeyleri açısından anlamlı fark bulunmadı.

Tablo 3. Grup 1 ve Grup 3 karşılaştırması

\begin{tabular}{lcc}
\hline \multicolumn{1}{c}{$H D(+) E D(+) / H D(-) E D(+)$} & $H c y$ & Testosteron \\
\hline Mann-Whitney U & 413,000 & 262,000 \\
Wilcoxon W & 1494,000 & 515,000 \\
$Z$ & $-1,477$ & $-3,020$ \\
P değeri &, 140 &, 003 \\
\hline
\end{tabular}

ED olan hastalar kendi aralarında; IIEF skorlarına göre 12-21 hafif ve 5-11 orta+şiddetli şeklinde iki gruba ayrilıp toplamda altı grup oluşturulduğu ve veriler tekrar değerlendirildiğinde; Gruplar arasında Hcy değerleri açısından anlamlı olarak farklı olduğu saptandı (Tablo 4).

Mann-Whitney U testi ile ikili gruplar halinde karşılaştırma yapıldığı zaman orta+şiddetli derecede ED'si olan gruplar karşılaştırıldığı zaman HD hastalarının Hcy değerlerinin anlamlı olarak yüksek olduğu saptandı. $(\mathrm{p}=0,003)$. (Tablo 5). Yine aynı şekilde KBY hastalarında, orta+şiddetli derecede ED'si olanlar ve ED'si olmayanlar arasında anlamlı şekilde Hcy değerlerinin ( $\mathrm{p}=0,016)$ ED’li grupda

Tablo 2. Gruplandırma sonucu Kruskal Wallis test değerlendirmesi

\begin{tabular}{|c|c|c|c|c|c|}
\hline & 1. Grup & 2. Grup & 3. Grup & 4. Grup & \multirow{2}{*}{$P$ değer } \\
\hline & $H D(+) E D(+)$ & $H D(+) E D(-)$ & $H D(-) E D(+)$ & $H D(-) E D(-)$ & \\
\hline Yaş & $48,2 \pm 10,6$ & $36,4 \pm 9,5$ & $52,2 \pm 10,3$ & $45,5 \pm 9,3$ & 0,01 \\
\hline Hcy & $12,36 \pm 7,4$ & $9,00 \pm 7,05$ & $9,36 \pm 3,72$ & $8,67 \pm 2,59$ & 0,260 \\
\hline Total Testosteron & $2,58 \pm 0,98$ & $3,05 \pm 0,7$ & $3,74 \pm 1,65$ & $2,88 \pm 1,00$ & 0,012 \\
\hline LDL & $94 \pm 26$ & $94 \pm 28$ & $103 \pm 29$ & $102 \pm 24$ & 0,681 \\
\hline Total Kolestrol & $155,8 \pm 36,9$ & $159,2 \pm 41$ & $172 \pm 36,5$ & $164,2 \pm 25$ & 0,597 \\
\hline Glukoz & $94 \pm 15,05$ & $90 \pm 10,4$ & $88,2 \pm 12,9$ & $89 \pm 9,3$ & 0,711 \\
\hline VKi & $24,3 \pm 3,8$ & $24 \pm 2,8$ & $27,1 \pm 3$ & $25,7 \pm 3,07$ & 0,004 \\
\hline Trigliserit & $157 \pm 65$ & $148,8 \pm 54$ & $136,5 \pm 68,8$ & $136 \pm 36,1$ & 0,393 \\
\hline Sigara içen & $\% 43$ & $\% 45$ & $\% 55$ & $\% 41$ & \\
\hline Hasta sayısı & 23 & 11 & 45 & 12 & \\
\hline
\end{tabular}


Tablo 4. Alt grup sonrası değerlendirme

\begin{tabular}{lcccccc}
\hline & 1. Grup & 2. Grup & 3. Grup & 4. Grup & 5. Grup & 6. Grup \\
\cline { 2 - 7 } & $H D(-)$ & $H D(-)$ & $\begin{array}{c}H D(-) \\
E D(\text { Orta+ } \\
\text { Şiddetli) }\end{array}$ & $\begin{array}{c}H D(+) \\
E D(-)\end{array}$ & $\begin{array}{c}H D(+) \\
E D(\text { Hafif) }\end{array}$ & $\begin{array}{c}\text { ED (Orta+ } \\
\text { Şiddetli) }\end{array}$ \\
\hline Yaş & $45,5 \pm 9,35$ & $53,9 \pm 10,1$ & $50,4 \pm 10,5$ & $36,4 \pm 9,5$ & $44,5 \pm 10,4$ & $54 \pm 8,4$ \\
Hcy & $8,67 \pm 2,5$ & $9,49 \pm 3,62$ & $9,2 \pm 3,91$ & $9 \pm 7,05$ & $9,61 \pm 6,54$ & $16,63 \pm 6,9$ \\
Testosteron & $2,88 \pm 1$ & $3,61 \pm 1,65$ & $3,86 \pm 1,67$ & $3,05 \pm 0,7$ & $2,5 \pm 0,96$ & $2,7 \pm 1,07$ \\
VKi & $25,7 \pm 3,07$ & $26,9 \pm 2,57$ & $27,3 \pm 3,4$ & $24,0 \pm 2,8$ & $24,6 \pm 4,36$ & $23,8 \pm 3,08$ \\
Kişi sayısı & 12 & 24 & 22 & 11 & 14 & 9 \\
\hline
\end{tabular}

yüksek olduğu görüldü. Bu durum orta+şiddetli düzeyde erektil disfonksiyonun KBY'li hastalarda homosistein ile ilişkili olabileceğini düşündürmektedir. ED’si olmayan gruplar arasında Hcy değerleri açısından anlamlı fark bulunmamıştır (Tablo 6).

Kruskal Wallis testi uygulandığında KBY'li HD'ye giren grup ile KBY'si olmayan grup karşılaştırıldığı zaman ortalama Hcy; HD'ye giren grupta ortalama olarak daha yüksek olmasına rağmen aralarında anlamlı fark bulunamamıştır.

Tablo 5. HD (-) ED (+) ve HD (+) ED (+) gruplarının karşılaştırılması

\begin{tabular}{lc}
\hline$H D(-) E D(+) / H D(+) E D(+)$ & $H c y$ \\
\hline Mann-Whitney U & 30,000 \\
Wilcoxon W & 283,000 \\
$Z$ & $-3,003$ \\
P değeri & 0,003 \\
\hline
\end{tabular}

Tablo 6. HD (-) ED (-) ve HD (+) ED (-) gruplarının karşılaştırılması

\begin{tabular}{lll}
\hline$H D(-) E D(-) / H D(+) ~ E D(-)$ & $H C Y$ & Testosteron \\
\hline Mann-Whitney U & 129,000 & 70,500 \\
Wilcoxon W & 207,000 & 125,500 \\
Z &,- 108 & $-1,606$ \\
P değeri & 0,929 & 0,129 \\
\hline
\end{tabular}

Tablo 8. KBY ve KBY olmayan grubun Hcy karşılaştırılması

\begin{tabular}{llll}
\hline & $H D(+)$ & $H D(-)$ & $P$ değeri \\
Hcy & $11,27 / 7,37$ & $9,22 / 3,51$ & 0,430 \\
\hline
\end{tabular}

(Tablo 7 ve Tablo 8). Bu gruplar arasında yaş, total testosteron ve VKİ arasında anlamlı fark bulunmuştur. Total testosteronun, KBY grubunda düşük saptanması güncel literatürle uyumlu görülmektedir.

Çalışmada uygulanan bir diğer analiz yöntemi de sıralı lojistik regresyon modeli olmuştur. ED dereceleri açıklanan değişken olarak alınmıştır. Yaş, HD’ye girip girmeme durumu, Hcy, sigara ve testosteron açılayan değişken olarak alınmıştır. Analiz sonucu Hcy $(\mathrm{p}=0,011)$ yaş $(\mathrm{p}=0,05)$ ve sigara $(\mathrm{p}=0,09)$ açıklayıcı değişken (Tablo 9) olabilmesi için anlamlı bulunmuştur. Sıralı lojistik regresyon modeli uygulanmıştır.

Tablo 9. Hcy, yaş ve sigara açıklayıcı değişken karşılaştırılması

\begin{tabular}{lllll}
\hline & Katsayı & $P$ değeri & Alt sınır $(\mathrm{Cl})$ & Üst sınır $(\mathrm{Cl})$ \\
\hline Yaş &, 037 &, 005 &, 011 &, 063 \\
Hcy &, 077 &, 011 &, 018 &, 136 \\
Testosteron &, 147 &, 171 &,- 064 &, 358 \\
[Sigara=0] &,- 777 &, 009 & $-1,357$ &,- 197 \\
{$[$ Sigara=1] } & $0 a$ &. &. &. \\
{$[\mathrm{HD}=0]$} &, 382 &, 224 &,- 234 &, 998 \\
{$[\mathrm{HD}=1]$} & $0 a$ &. &. &. \\
\hline
\end{tabular}

Tablo 7. KBY ve KBY olmayan hastaların karşılaştırılması

\begin{tabular}{lllllllll} 
& Yaş & Hcy & Testosteron & LDL & T. Kolestrol & Gluk & BMI & Trigliserit \\
\hline Chi-square & 6,942 &, 622 & 6,326 & 1,494 & 1,380 & 1,217 & 11,272 & 2,599 \\
df & 1 & 1 & 1 & 1 & 1 & 1 & 1 & 1 \\
Asymp. Sig. & 0,008 & 0,430 & 0,012 & 0,222 & 0,240 & 0,270 & 0,001 & 0,107 \\
\hline
\end{tabular}

Test Statistics ${ }^{\mathrm{a}, \mathrm{b}} \quad$ a. Kruskal Wallis Test, b. Değişken grup: HD




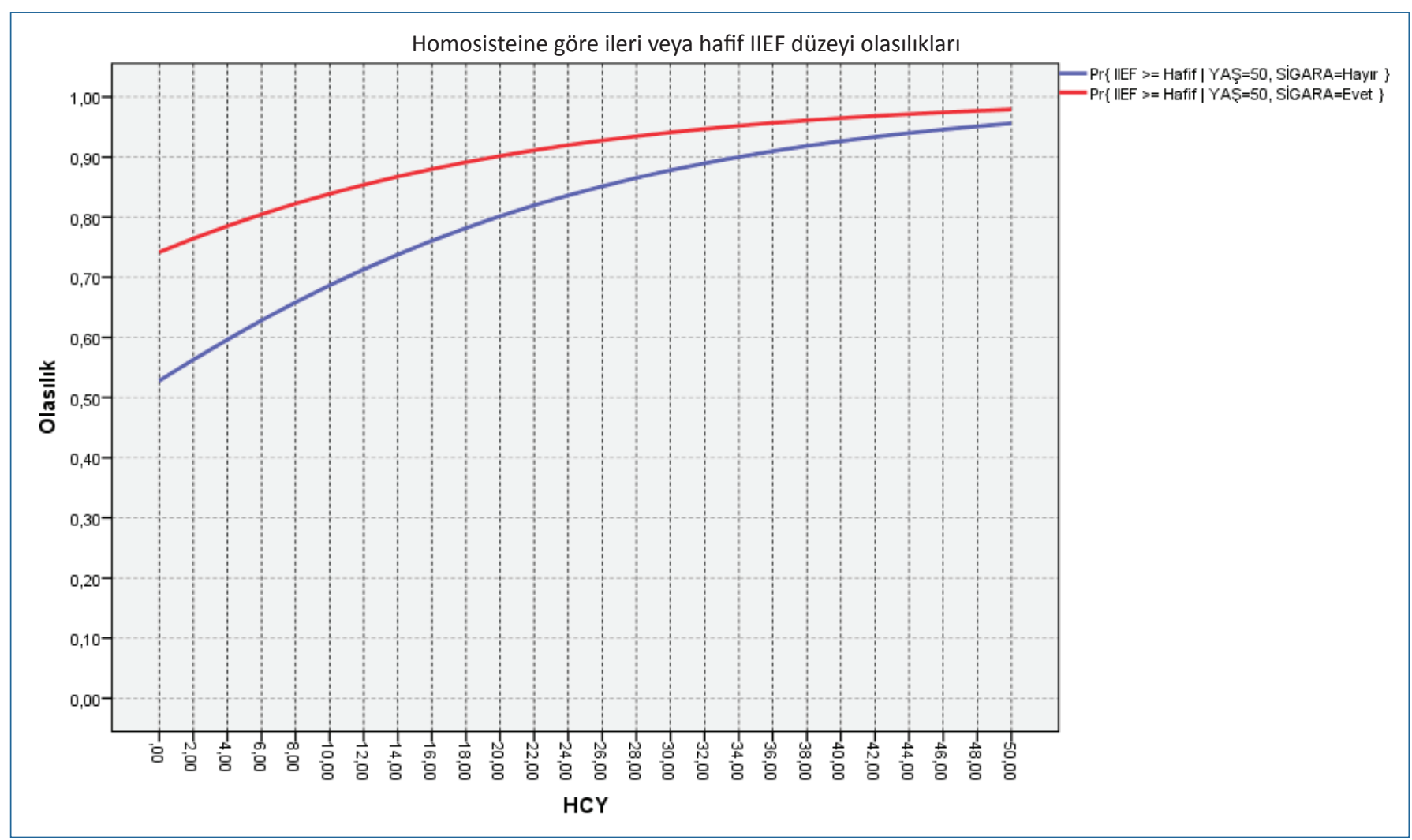

Şekil 1. Sigara içmeyen grupta Hcy değerleri ve ED arasında ilişki.

Yapılan analizde, yaş 50 sabit alındığında, Hcy değerlerinin artmasının, sigara içen ve içmeyen, her iki grupta da ED riskini arttırdığı yönünde sonuçlar elde edilmiştir. Sigara içen hastalarda, ED riskinin içmeyen gruba göre daha fazla olduğu görüldü. Sigara içmeyen hastalarda da aynı şekilde, Hcy değerlerindeki artmanın ED riskini arttırdığı görüldü. (Şekil 1).

\section{TARTISTMA}

Erektil disfonksiyon (ED), başarılı bir cinsel ilişki için gerekli ereksiyonun sağlanamaması ve/veya sağlansa bile sürdürülememesi olarak tanımlanır. ED etyolojisinde, vasküler, hormonal, nörolojik, psikolojik rahatsızlıklar, yaşlanma ve yaşam tarzı ile ilgili birçok faktör rol oynamaktadır. ${ }^{[11]}$

Hiperkolesterolemi, hipertansiyon, diyabet, yaşlanma ve KBY ile ilgili klinik ve preklinik çalışmalar, vaskülojenik ED gelişiminde endotelyal disfonksiyonun kritik bir faktör olduğunu göstermiştir. ${ }^{[12]}$ Endotelyal disfonksiyon, bozulmuş vazodilatasyon ile yakından ilişkilidir. Endotelyal hücreler, güçlü bir vazodilatatör nörotransmitter olan ve özellikle peniste olmak üzere vasküler duvar fonksiyonlarının regülasyonunda rol oynayan NO'in primer kaynağıdır. ${ }^{[13]}$
Hiperhomosisteineminin ateroskleroz gelişimi ve kardiyovasküler morbidite/mortalite açısından bağımsız bir risk faktörü olduğu bilinmektedir. ${ }^{[14]}$ Öte yandan hiperhomosisteineminin sağlıklı popülasyon ve kronik böbrek yetmezliği hastaları için kardiyovasküler risk faktörü olduğu birçok çalışmada gösterilmiştir. KBY olan hastalarda \%85-90'a varan hiperhomosisteinemi prevalansı ve diğer pek çok predizpozan faktör nedeniyle aterosklerotik hastalıklar açısından oldukça yüksek mobidite/mortalite riski söz konusudur. ${ }^{[15]}$

Arnadotti ve ark. glomerüler filtrasyon hızı $5-105 \mathrm{~mL} /$ $\mathrm{dk}$ arasında olan 77 hastada total homosistein düzeyi ile glomerülar filtrasyon hızının ters orantı gösterdiğini saptamışlardır. ${ }^{[16]}$

Böbrek fonksiyonunun bozulmasıla homosistein düzeyinde progressif olarak yükseldiğini ve artmı̧ Homosisteinin yükselmiş değerlerinin endotelyal disfonksiyona neden olabileceğini gösteren çok sayıda in vitro ve in vivo çalışma mevcuttur. Ek olarak, homosistein üzerinden meydana gelen endotelyal disfonksiyonun ED patofizyolojisinde rol oynadığını gösteren klinik ve deneysel çalışma da rapor edilmiştir. ${ }^{[7,17-20]}$ HHcy vasküler dokuya etkisi, NO ilişkili vazodilatasyonu azaltarak olmaktadır. ${ }^{[0,17]}$ Yapılan hayvan çalışmalarında HHcy'nin kavernozal düz kasta NO aracilı gevşemeyi azalttığı gösterilmiştir. ${ }^{[18,20]}$ 
HHcy ve ED ilişkisini sorgulayan klinik çalışmalar incelenirse; 2006 yılında Demir ve ark.'nın yapmış olduğu bir araştırmada, non-diyabetik, erektil disfonksiyonu penil Doppler ultrasonografi ile doğrulanan hastaların, homosistein düzeylerinin kontrol grubuna göre anlamlı olarak yüksek olduğu saptanmışır. Ayrıca ED'si mevcut grubun \%80'inin Hcy değerleri 12,1 mmol/L'nin üzerinde saptanmıştır. ${ }^{[7]}$

Çalışmamızda homosistein değerleri, KBY'li grupta KBY olmayan gruba göre yüksek bulunmuştur. Buna karşılık, gruplar arası farklılığın istatistiksel açıdan anlamlı olmadığı saptanmamıştır. Bu bulgu; HD programında yer alan hastalara rutin olarak folat ve vitamin B12 tedavisinin uygulanması olabilir. Çalışmamızda, folat ve vitamin B12 almayan bir grup oluşturulması, KBY'li hastalarda daha yüksek homosistein değerleri elde etmemize olanak sağlayabilirdi. Bu durumun da, HHcy'nin, ED ile olan ilişkisini ortaya koymak açısından, daha sağlam sonuçlar elde etmemize imkan verebileceğini düşünmekteyiz. Buna karşıllı bu tarz bir yaklaşımın genel etik kurallar açısından uygulanması olanaklı görülmemektedir.

Çalışmaya alınan hastaların testosteron düzeylerinin normal değer aralıklarında olmasına dikkat edilmekle birlikte; KBY'li olan ve olmayan gruplar karşılaştırıldığında; testosteron değerleri arasında, KBY'li grupta ortalama testosteron değerinin anlamlı olarak düşük olduğu gözlendi. Bu sonuç güncel literatürle uyumlu olarak değerlendirildi.

Çalışmamızda, ED si olan KBY hastalarıyla ve ED'si olan KBY'si olmayan hastalar karşılaştırıldığında; Hcy değerleri arasında anlamlı bir fark olmadığı saptanmıştır. Buna karşılık; ED grupları şiddetli+orta ve hafif olarak sınıflandırıldıktan sonra yapılan karşılaştırmada; Hcy düzeyi, şiddetli+orta düzeyde ED si olan KBY'li ve KBY olmayan gruplar arasında, KBY'li grupta anlamlı olarak yüksek saptand. Ek olarak, bu iki grup arasında testosteron seviyeleri arasında anlamlı fark olmadığı bulunmadı. Bu sonuç, KBY hastalarda, homosistein düzeylerinin artmasının, şiddetli ve orta düzeyde $\mathrm{ED}$ gelişiminde etkisi olabileceği yönünde yorum yapmamıza olanak vermektedir. Bununla birlikte, geniş hasta sayısı içeren ileri çalışmaların istatistiksel açıdan daha güvenilir yorumlar yapılmasına katkı sağlayacağı açıktır. Ayrıca ek olarak, erektil disfonksiyonun şiddetinin değerlendirilmesinde tek başına kullanılan IIEF sorgulama formuna ek olarak penil Doppler ultrasonografi vb. daha detaylı testlerin kullanılmasının tanısal doğruluk oranını arttırdığı göz önünde bulundurulmalıdır.

Sıralı lojistik regresyon modeli uygulanarak yapılan analizde; homosisteinin yükselmesinin, yaş ve sigaradan bağımsız olarak, ED riskini arttırdığı görülmüştür. Bu sonuçlarda literatürde mevcut olan, HHcy nin ED gelişmesi yönünde bağımsız bir risk faktörü olduğunu gösteren çalışmalarla uyumlu görünmektedir.

Son olarak prospektif olarak gerçekleştirilen araştırmamızda; çalışma grupları arasındaki hasta yaşlarının homojen olarak dağılmamış olması, çalışmamızın eksik yönlerinden biri olarak kabul edilebilir. Buna karşılık çalışmanın prospektif yapısı; yaş gruplarının homojenizasyonunu güçleştirmiştir. Çalışmanın devamında, hasta sayılarının arttırılması ile bu tartışmalı bulgunun da giderilmesi mümkün olabilir.

\section{KAYNAKLAR}

1. Levitan D, Moser SA, Goldstein DA, Kletzky OA, Lobo RA, Massry SG. Disturbances in the hypothalamic-pituitary-gonadal axis in male patients with acute renal failure. Am J Nephrol 1984;4:99-106.

2. Thambyrajah J, Landray MJ, McGlynn FJ, Jones HJ, Wheeler DC, Townend JN. Abnormalities of endothelial function in patients with predialysis renal failure. Heart 2000;83:205-9

3. Schaefer RM, Kokot F, Wernze H, Geiger H, Heidland A. Improved sexual function in hemodialysis patients on recombinant erythropoietin: a possible role for prolactin. Clin Nephrol 1989;31:1-5.

4. Navaneethan SD, Vecchio M, Johnson DW, Saglimbene V, Graziano G, Pellegrini F, et al. Prevalence and correlates of self-reported sexual dysfunction in CKD: a meta-analysis of observational studies. Am J Kidney Dis 2010;56:670-85. doi: 10.1053/j.ajkd.2010.06.016

5. Mesquita JF, Ramos TF, Mesquita FP, Bastos Netto JM, BastosMG, Figueiredo AA. Prevalence of erectile dysfunctionin chronic renal disease patients on conservative treatment. Clinics (Sao Paulo) 2012;67:181-3.

6. Nassir A. Erectile dysfunction risk factors for patients entering dialysis programme. Andrologia 2010;42:41-7. doi: 10.1111/j.1439-0272.2009.00954.x

7. Demir T, Comlekci A, Demir O, et al. Hyperhomocysteinemia: a novel risk factor for erectile dysfunction. Metabolism 2006;55:1564-8. doi: 10.1016/j.metabol.2006.03.019

8. Jiang X, Yang F, Tan H, et al. Hyperhomocystinemia impairs endothelial function and eNOS activity via PKC activation. Arterioscler Thromb Vasc Biol 2005;25:2515-21. doi: 10.1161/01. ATV.0000189559.87328.e4

9. McDowell IF, Lang D. Homocysteine and endothelial dysfunction: a link with cardiovascular disease. J Nutr 2000;130(2S Suppl):369S-72S.

10. Tawakol A, Omland T, Gerhard M, Wu J, Creager MA. Hyperhomocyst(e)inemia is associated with impaired endothelium dependent vasodilatation in humans. Circulation 1997;95:111921.

11. Derosa G, Romano D, Tinelli C, et al. Prevalence and associations of erectile dysfunction in a sample of Italian males with type 2 diabetes. Diabetes Res Clin Pract 2015;108:329-35. doi: 10.1016/j.diabres.2015.01.037

12. Watts GF, Chew KK, Stuckey BG. The erectile-endothelial dysfunction nexus: new opportunities for cardiovascular risk prevention. Nat Clin Pract Cardiovasc Med 2007;4:263-73. doi: $10.1038 /$ ncpcardio0861 
13. Toda N, Ayajiki K, Okamura T. Nitric oxide and penile erectile function. Pharmacol Ther 2005;106:233-66. doi: 10.1016/j. pharmthera.2004.11.011

14. Scott JM. Homocysteine and cardiovascular risk. Am J Clin Nutr 2000;72:333-4.

15. Fan SLS, Almond MK, Ball E, Evans K, Cunningham J. Pamidronate therapy as prevention of bone loss following renal transplantation. Kidney Int 2000;57:684-90. doi: 10.1046/j.15231755.2000.00890.x

16. Arnadotti M, Hultberg B, Nilsson-Ehle P, Thysell H. The effect of reduced glomerular filtration rate on plasma total homocysteine concentration. Scand J Clin Lab Invest 1996;56:41-6. doi: 10.3109/00365519609088586

17. Giovannone M, Busetto GM, Antonini G, et al. Hyperhomocysteinemia as an Early Predictor of Erectile
Dysfunction: International Index of Erectile Function (IIEF) and Penile Doppler Ultrasound Correlation With Plasma Levels of Homocysteine. Medicine (Baltimore) 2015;94:e1556. doi: 10.1097/MD.0000000000001556

18. Khan M, Thompson C, Elmsley A, et al. The interaction of homocysteine and copper markedly inhibits the relaxation of rabbit corpus cavernosum: new risk factors for angiopathic erectile dysfunction? BJU Int 1999;84:720-4.

19. Yan WJ, Yu N, Yin TL, Zou YJ, Yang J. A new potential risk factor in patients with erectile dysfunction and premature ejaculation: folate deficiency. Asian J Androl 2014;16:902-6. doi: 10.4103/1008682X.135981

20. Selhub J, Jacques PF, Wilson PW, Rush D, Rosenberg IH. Vitamin status and intake as primary determinants of homocysteinemia in an elderly population. JAMA 1993;270:2693-8. 